\title{
Explaining the diversity of policy responses to platform-mediated short-term rentals in European cities: a comparison of Barcelona, Paris and Milan
}

Final accepted version, 17.06.2019

Aguilera, T., Artioli F., and Colomb, C. (2019) Explaining the diversity of policy responses to platform-mediated short-term rentals in European cities: a comparison of Barcelona, Paris and

Milan. Environment and Planning A. Published online on 23 July: http://dx.doi.org/10.1177/0308518X19862286

\section{Authors:}

\section{Thomas Aguilera}

Political Science, Sciences Po Rennes, France

\section{Francesca Artioli}

Political Science \& Planning, Lab'Urba, Ecole d'Urbanisme de Paris, Université Paris-Est

Créteil, France

\section{Claire Colomb}

Urban Studies \& Planning, The Bartlett School of Planning, University College London, UK

Corresponding author: c.colomb@ucl.ac.uk 


\begin{abstract}
Short-term rentals facilitated by online platforms (like Airbnb) have recently become an object of intense debate, leading many city governments to pass new regulations attempting to control both their proliferation and platform activities. While these policy responses vary greatly from city to city, there is little comparative research to explain this diversity. This paper employs a sociological approach to public policy analysis to compare the politicization process, collective action around, and regulation of platform-mediated short-term rentals (PM-STR) in three cities - Barcelona, Paris and Milan. They were chosen to represent most-dissimilar cases in terms of regulatory outputs, both in terms of stringency (weak in Milan, intermediate in Paris, strong in Barcelona) and choice of policy sectors (sharing economy and tourism in Milan, housing and land use in Paris, urban planning and tourism in Barcelona). Two main findings emerged from the comparison. First, the differences between regulations can be explained by the type of actors who politicized the issue in the first place and framed it within a specific policy sector, the pre-existing policy instruments traditionally used in that sector, and the distribution of competences between the city and higher tiers of government. Second, the regulations remain continuously subject to intense political mobilisation by six types of actors with clashing interests: professional STR operators, associations of hosts or 'home-sharers', the hotel industry, residents' associations or citizens' movements, 'sharing economy' advocates, and corporate platforms. Each actor constructs different narratives regarding PMSTR, claiming different types of rights in this contentious politics of regulation.
\end{abstract}




\section{Introduction}

In the space of a few years, the impacts of urban tourism - and more broadly of increasing transnational mobility flows on urban spaces - have become a highly contentious issue in many cities around the world. Citizens' mobilizations, politicians and academics have started to criticise the adverse effects of visitor flows on the transformation of neighbourhoods, housing markets and local economies, and on the daily life of long-term residents (Novy and Colomb, 2016, 2019). The growth of short-term ("holiday") rentals (STR) has recently become one of the most conflictive issues, in part due to its perceived contribution to processes of gentrification (Cócola Gant, 2016a; Gravari-Barbas and Guinand, 2017; Cócola Gant and Gago, this issue). The proliferation of STR was facilitated by the emergence of new forms of 'platform capitalism' (Srnicek, 2017) shaped by for-profit online platforms which organise supply and demand and take a commission for intermediation - the most well-known being Airbnb. ${ }^{1}$ The issue of platform-mediated short-term rentals (hereafter referred to as PM-STR) has become widely discussed in the media and local political arenas. Actors as different as housing activists and the hotel industry have begun to challenge the impacts of PM-STR on housing markets, residents, and incumbent economic actors. As a result, some city governments have recently passed new regulations attempting to control the proliferation of STR and the activities of platforms. In the European context, the responses of city governments have been very diverse. Some have taken strong regulatory measures to curb or ban the growth of STR, as in Berlin, Amsterdam or Barcelona (APUR, 2018). Others have tried to find a middle ground between attractiveness to visitors and the protection of residential uses, like in Paris or London. A few, like Milan, have opted to tackle the issue through light regulatory approaches encouraging the development of the so-called 'sharing economy'. In some cities, no regulatory measures have been adopted, but public demands for regulation have intensified. In some cases, national governments have passed new laws, as in the UK and France. How to explain such a geographical diversity of reactions, and of subsequent scales and forms of regulation, of PM-STR in European cities?

Although now abundant, the existing literature on STR, digital platforms and their impacts on cities has taken the "public problem" of PM-STR for granted, and has not engaged much with the process of politicization, and the diverse policy responses to these phenomena, in a comparative manner. In this paper we seek to explore, and explain, the differences in how the "PM-STR problem" has been framed and regulated between different places. We develop a framework for understanding differences between local policy responses based on the premise that such responses cannot be simply viewed as the result of different structural political-economic conditions, but as a product of the struggle between collective actors with various interests, modes of action and narratives embedded into place-specific institutional arrangements. The paper thus uses a sociological approach to public policy to analyse the processes of politicization and collective action around, and different regulations of, PM-STR in three large European cities: Barcelona, Paris and Milan. These were chosen to represent 'most-dissimilar' cases in terms of regulatory outputs, both in terms of stringency (weak in Milan, intermediate in Paris, strong in Barcelona) and choice of policy sectors (sharing economy and tourism in Milan, housing and land use in Paris, and urban planning and tourism

\footnotetext{
${ }^{1}$ Airbnb was created in 2008 in San Francisco as an online platform allowing individual owners/tenants to advertise their home, or part thereof, for short-term rental. According to its website, in June 2019 there were over 6 million listings in 191 countries.
} 
in Barcelona). The policy issue at stake is two-fold: STR themselves, and their mediation through new digital platforms which are the vehicle through which the phenomenon has become more widespread.

The paper is organised as follows. After briefly reviewing recent scholarship on the impacts of PM-STR on cities and introducing our theoretical and analytical framework, in the second part we present our comparative methodology and trace the processes of politicization, actors' mobilisation and policy framing in each city. In the third section, we compare those processes to explain how and why they have led to a different regulation of PM-STR in each of the three cities. We point out, on the one hand, the main factors that can explain these differences and on the other, the common features and actors in the contested 'politics of regulation'.

\section{PM-STR and cities: the need to research politicization, framing and regulation in a comparative perspective}

The short-term rental of accommodation units to visitors as a commercial activity is not new: in most West European countries, this economic activity has been regulated for many years. What has turned this practice into an object of controversy is the mutation caused by the emergence of digital platforms such as Airbnb, which has encouraged more actors to engage in PM-STR. Tourism studies scholars first analysed the changes in individual practices generated by this 'disruptive innovation' (Guttentag, 2015; Dredge and Gyimóthy, 2017; Prayag and Ozanne, 2018). Several practices can be subsumed under the term STR: (i) commercial STR of a full unit not normally used as a primary residence; (ii) temporary STR of a full unit while the main resident is away; and (iii) rental of a portion of a primary residence with the host present ("home-sharing"). The first two are usually the most contentious, while the last two are often described as forming part of the 'collaborative' or 'sharing' economy. Regulatory attempts by city governments often apply different rules to each type of practice.

The motivations of STR operators vary, from a desire for inter-cultural exchanges, to a household's need for extra income (Stabrowski, 2017), to the search for high returns by speculative actors and multi-property owners. On the demand side, the increasing popularity of STR among travellers is due to cost saving and the desire for contact with "locals" (Tussyadiah and Pesonen, 2018). Advocates of PM-STR argue that they democratize travel through lower costs; generate extra income for households; foster positive social encounters; contribute to a better territorial spread of tourist accommodation; and generate "trickledown effects" for local economies (Airbnb, 2018). Critics of PM-STR argue that they disturb local residents' life; pose security/safety issues for users; evade taxation; generate unfair competition for hotels (Zervas et al., 2017); are no longer part of the "sharing economy" due to appropriation by rent-seeking actors (Crommelin et al., 2018; Slee, 2016); entrench socioeconomic and racial inequalities (Schor and Attwood-Charles, 2017); and generate adverse impacts on housing markets and the socio-economic fabric of neighbourhoods.

The latter impacts - caused by STR type (i) - have become particularly contentious: in highdemand cities, studies have found signs that the proliferation of STR has contributed to a decline in the housing stock available for long-term occupation and to an increase of rental prices in specific neighbourhoods (e.g. Barron et al., 2017 on the USA; Schäfer and Hirsch, 2017 on Berlin; Gurran and Phibbs, 2017 on Sydney; Wachsmuth et al., 2017 on Canada). It 
should be noted, though, that there are complex methodological challenges (which cannot not be addressed here) in measuring the impacts of STR on housing markets (Wachsmuth, 2017; Cócola Gant, 2018). It is also difficult to isolate them from other relevant dynamics and factors of urban socio-spatial change, in particular: broader processes of gentrification and their multiple causes (Lees et al., 2015); the increasing importance of exchange value over use value through the commodification and financialization of housing units (Aalbers, 2016); or transnational investments in housing by non-residents as a second home, a 'safe haven' or a profitable asset (see Paris, 2009 on second home ownership and housing markets; Deverteuil and Manley, 2017 on 'high net-worth individuals' and 'pied-a-terre urbanism' in London; Mendes, 2018 and Cócola Gant and Gago, this issue on the impact of the Portuguese 'Golden Visa', foreign investment and rental deregulation policies on the Lisbon housing market).

A review of the scholarly literature on for-profit digital platforms and cities (Artioli, 2018) highlighted five emergent themes: the nature and boundaries of platform-mediated exchanges; their size and socio-economic organisation; their income and spatial distributional effects; their effects on existing markets; and, to a lesser extent, their regulation and governance. The issue of regulation was first addressed by American legal scholars who analysed how local zoning codes and ordinances have been used (and challenged) to regulate STR (e.g. Gottlieb, 2013; Palombo, 2015; Widener, 2015). Those approaches tend, however, not to tackle the political and social struggles that emerge around regulation. One exception stems from Pollman and Barry (2017), who offer an interesting conceptualisation of corporate platforms as 'regulatory entrepreneurs' striving to influence the public regulation of their activities. In critical urban studies, some authors have highlighted the role played by transnational corporate platforms in urban politics and public policy, epitomized by the campaigning activities of Airbnb in San Francisco in 2015 against the so-called "Proposition F" intended to limit PM-STR (McNeill, 2016; Stabrowski, 2017; Sharp, 2018). More recently, planning scholars have investigated how local planning policies have responded to PM-STR (Gurran and Phibbs, 2017; Gurran, 2018; Holman et al., 2018; Ferreri and Sanyal, 2018; Leshinsky and Schatz, 2018), showing that traditional zoning or land use regulatory mechanisms are not very effective.

Building on this growing body of scholarship, we argue that the socio-political struggles, forms of collective action, agenda-setting and policy framing processes around the regulation of PMSTR have been relatively overlooked. Moreover, existing studies tend to focus on one city (exceptions being Dredge et al., 2016; Smorto, 2016; Wegmann and Jiao, 2017; Crommelin et al., 2018; Nieuwland and van Melik, 2018). Fine-grained comparative approaches are needed to develop explanations about the differences in local political responses to transnational 'shared shocks' like the advent of Uber or Airbnb, which are often 'refracted into divergent struggles over particular national practices' (Locke and Thelen, 1995: 338). Some political scientists and sociologists have started to explore the comparative politics of the platform economy and its regulation, in particular Thelen (2018) on Uber and Courmont (2018) on Waze, but to our knowledge there are no comparative studies of the local politics and regulatory policies surrounding PM-STR yet.

We seek to bridge this gap by adopting a comparative, sociological approach to public policy, rooted in the basic postulate that political 'problems' result from social and political constructions relative in time and space (Becker, 1963). This underpins various approaches to 
policy studies developed over the past decades by North American and European scholars as an alternative to the dominance of rational choice theory in policy analysis (Fischer, 2003). Accordingly, public policies are devised in response to a 'public problem' of a perceived collective nature, which is discursively constructed by political authorities and various social actors to justify some form of intervention. This process is underpinned by 'policy narratives' (Radaelli, 1999), i.e. a set of legitimizing arguments providing a rationale and framing of 'public problems' developed by specific actors. These narratives sometimes invoke specific collective or individual rights that constitute the foundation of public claims about regulation, as we will see.

In our analysis, we develop a careful examination of the social struggles which make PM-STR become a political issue in particular cities, and push governments to design public policies. These struggles contribute to open a 'public arena' in which actors (or coalitions) try to impose one particular policy framing - namely a particular definition of the problem (diagnostic) and expected solutions (prognostic) (Cress and Snow, 2000) - with the goal to shape the form and content of public policies. However, this process - from framing to agenda-setting and policy design - is never linear. First, some actors can mobilize resources to obstruct it in order to preserve their own interests and avoid regulation (Cobb and Ross, 1997). Second, in many policy fields, the framing can be shaped by pre-existing policy programs and instruments (Rose and Davies, 1994). More generally, a government's capacity to develop policies is shaped by the broader institutional arrangements that define the distribution of power and competences across various levels and branches of government (Hall, 1986). As we will see, policy instruments which existed before the birth of digital platforms matter, because policies entail some 'recycling' and are rarely pure innovations (Hood, 1983). Finally, our study takes into account the 'trans-sectorial' dimension of PM-STR, a phenomenon at the crossroads between different policy sectors within the remit of different administrative departments - housing, land use planning, economic development and tourism. In each sector, well-established actors defend situated interests with potentially contradictory goals. This requires an analysis of the competition around the assignment of the policy issue of PM-STR to an existing sector, or, by contrast, of the emergence of new cross-sectoral policies or autonomization of a new sector. Governing new issues in a cross-sectoral way can be heavily constrained by existing administrative divisions and routines (Muller, 1985), or can become an opportunity to transform existing sectors and experiment with new instruments.

Our approach to the regulation of PM-STR in European cities does not discard the possible influence of different structural socio-economic conditions as sources of variation in local political responses between cities. There is no doubt that the intensity of tourism pressures may influence the saliency of the issue on local agendas, and the overall increase and geographical spread of STR in a particular city. Equally, the scarcity of affordable housing, or the quantity of social housing available in a given place, shapes the way in which social movements and politicians may consider PM-STR as a threat to the capacity of local residents to 'stay put' in their city. However, our postulate is that these conditions are not the main, or sole, factors to explain the processes of politicization of PM-STR - the focus of this paper. If the quantitative importance of tourist flows was the main explanatory variable, one would expect massive grassroots and political mobilisations against mass tourism in Paris - the most visited city in the world - that would frame the PM-STR issue through this lens, as has been the case in Barcelona (Novy and Colomb, 2016). As we will see, this was not the case in Paris. The 
intuitive argument assuming that the presence of strong social movements (combined with an electoral window) is a key factor to explain the quick and strong politicization of PM-STR, which works for Barcelona, does not apply to Paris. Equally, one may hypothesize that the defence of the right to rent one's home might be more vocally mobilized in all Southern European cities where there is a high rate of homeownership, and where the negative effects of the post-2008 recession on residents' income have been strongly felt. The significant differences between the Barcelona and Milan cases, outlined below, contradict this hypothesis. Paying attention to actors' resources, modes of framing, narratives, incentives and power positions in a given context is thus fundamental, as these actors constitute the agency that give meaning and priority to particular structural conditions (e.g. in relation to tourism, housing or economic development) and eventually emphasize them (or not), always selectively, for policy development. As Thelen shows in her comparative study of the responses to the emergence of the transportation platform Uber in the United States, Germany, and Sweden, reactions can vary 'from welcome embrace and accommodating regulatory adjustments to complete rejection and legal bans' (2018: 938), because the regulatory tensions that a platform provokes in different countries 'mobilize different actors, inspire the formation of different coalitions, and shape the terms on which conflicts over Uber are framed and fought' (Ibid.).

\section{How PM-STR became a policy issue in European cities: the cases of Barcelona, Paris and Milan}

In this comparison we seek to explore, and explain, the differences in how the "PM-STR problem" has been framed and regulated in different cities. Through a 'variation-finding' approach, we seek to 'establish a principle of variation in the character or intensity of a phenomenon by examining systematic differences between instances' (Tilly, 1984: 82). We seek to uncover pluralist causalities (Pickvance, 2001) to explain how and why a cross-cutting global phenomenon affecting many cities produces different outcomes on the ground, thus contributing to ongoing debates about international comparison in urban studies (Robinson, 2011). The theoretical, conceptual and methodological premise of the paper is that we need to pay attention to social and political processes to understand differences between cities how and why particular socio-political struggles arise and develop in particular places - and not in others - around a similar urban 'issue', and which kind of policy regulations are adopted.

Our three-stage comparative research design was shaped by this aim. First, we selected what appeared to be three 'most-dissimilar' cases in terms of regulatory outputs. The focus of our cases, rather than the city itself, is the politicization process and formation of local collective action around the regulation of PM-STR in a particular place. Our case sampling was based on the dependent variable, i.e. the diversity of regulations that have been adopted, in order to answer the question: why cities have adopted such diverse forms of regulation, while facing the same phenomenon induced by similar firms? Among a sample of thirteen European cities we have been working on for a comparative research project on the regulation of PM-STR, for this article we chose to focus on Barcelona, Paris and Milan. These three cities are comparable in terms of area, density, importance in national contexts (as national or regional capitals), but face different structural conditions in terms of economy, tourism pressures, and housing market conditions (see Table 1). We chose these three cities because, at the end of the exploratory phase of the project in 2016 (which entailed a review of recent local and national 
media coverage of debates around PM-STR, and of the content of emerging regulations), they appeared to be the most dissimilar cases in terms of the types of regulation of PM-STR, both in terms of the level of stringency (weak in Milan, intermediate in Paris, strong in Barcelona) and choice of policy sectors (sharing economy and tourism in Milan, housing and land use in Paris, urban planning and tourism in Barcelona), as will be shown.

\section{Table 1. Context of the three cities: key facts and figures}

Second, we conducted detailed case-studies in each city to trace the mechanisms and processes of politicization and agenda-setting, and the actors involved in collective action around the issue of the regulation of PM-STR. Extensive documentary research was carried out (keyword searches in local and national media; analysis of transcripts of political debates, policy documents, and interest group statements), sometimes complemented by observation of public events. Through this, we identified who were the vocal interest groups and actors that publicly expressed a position on the issue and what their claims were. We then carried out approximately 15 semi-structured interviews in each city between 2016 and mid-2018 with representatives of those interest groups, who themselves named other relevant actors to interview through a snowballing technique. Interviewees were asked about their organisation's position, claims and activities about PM-STR regulation, and about their relationships with other actors.

Thirdly, by comparing the three case-studies, we identified in an inductive way the key variables that seem to explain the differences in regulatory outputs. The combination of a case-oriented and a variable-oriented approach makes it possible to develop a comparison respectful of the intricacy of each case while explaining differences and commonalities.

\section{Barcelona: grassroots mobilisations and new municipal agenda}

The case of Barcelona illustrates in an emblematic way how grassroots social mobilisations can politicize the issue of PM-STR. In the early 2000s, residents' associations in the historic district of Ciutat Vella began to denounce the nuisances caused by 'tourist apartments'. The number of STR in Barcelona sharply increased in the 2010s, fuelled by online platforms and by a 2012 decree by the Catalan regional government (which is responsible for setting the definition of STR as an economic activity), which created a light licensing system for 'accommodation for touristic use' (type (i) and (ii)). In the most affected districts, residents' associations began to convene public meetings to raise awareness of the problems generated by STR, lobby local councillors for action, and report illegal STR - often in vain. The Federation of Residents' Associations of Barcelona (FAVB) subsequently made the topic of tourism a key element of its campaigns, and STR became problematized within a broader critique of the negative effects of mass tourism on the city's physical and socio-economic fabric. Residents' concerns were increasingly mentioned in the local media, albeit in very different ways. They sometimes received sympathetic coverage, but more often than not, were criticized for being 'anti-tourism' (Milano, 2017) by various stakeholders who did not accept any challenge to the tourism sector - an undisputed cornerstone of the economic development strategy of successive municipal governments since the 1992 Olympic Games. 
Demands for STR control measures first found echo at the district level. In Ciutat Vella, a Pla $d^{\prime}$ Usos was approved in 2010 to regulate the opening and location of economic activities, and set a moratorium on new hotels and STR licenses. At the city-wide level, however, the political response was weak until 2014. In August of that year, a small incident received a lot of media attention and marked a turning point: three male tourists wandered around naked during daytime in the neighbourhood of La Barceloneta, unstopped by the police and causing outrage. Residents' associations organised vocal street protests to demand a stronger regulation of the city's tourism economy, and of STR in particular, under the motto "Barcelona is not for sale". The reaction of the then centre-right city government was to freeze new STR licenses and promise more inspectors to control illegal STR - a few months before municipal elections were due in May 2015.

The window of opportunity created by the local electoral campaign was seized by activists to shape the political agenda in a context where tourism had eventually become a public, contested issue. The FAVB prepared a list of demands about the regulation of tourism which was sent to all political parties, including a moratorium on new licenses for all forms of tourism accommodation. The left-wing citizen platform Guanyem Barcelona (created in June 2014 to run for the municipal elections, and rooted in the social movements that stemmed from the "15M" mobilizations - Eizaguirre et al., 2017) took many of those demands on board in its manifesto. In the spring of 2015, residents' associations and grassroots organisations formed a city-wide network (Assemblea de Barris per un Turisme Sostenible, ABTS) to counteract what they perceived as a "hegemonic" narrative on the role of tourism in the city. The fight against STR is a core element of its campaigns. The network is led by articulate activists who frame their concerns within a broader critique of Barcelona's urban development model, well aware that it is impossible to separate the effects of tourism from those of other processes driving neighbourhood change (e.g. lack of rent control, insufficient social housing, and speculative real estate practices). The framing of the "problem" of STR was no longer simply in terms of nuisances, but also of structural impacts on the housing market and on population decline (Cócola Gant, 2016b). Yet the arguments of the ABTS were opposed by professional STR operators, platform representatives, as well as individual residents occasionally engaged in STR practices. At local public meetings, tensions and disagreements around the issue were often palpable.

In May 2015, the citizen platform Guanyem Barcelona - renamed Barcelona en Comú - won a tight victory in the municipal elections, winning 11 out of 41 seats. Its figurehead - former housing activist Ada Colau - became Barcelona's new mayor. Among other themes, Barcelona en Comú promised to improve access to housing and change the city's urban development model, including a better regulation of tourism (Colau, 2014; Russo and Scarnato, 2018). Unsurprisingly, the implementation of this agenda proved challenging, given the minority position of the new political force in a politically-fragmented city council. Nevertheless, in July 2015 a one-year moratorium on new hotels and STR licenses was voted, while a plan regulating tourist accommodation would be prepared by the Urban Planning department. The Special Plan for Tourist Accommodation (PEUAT) was approved in January 2017 to reconcile four explicit rights - to housing, to rest and privacy, to sustainable mobility and to a healthy environment (Ajuntament de Barcelona, 2017). The plan is based on the principle of 'zero growth' of the total number of STR in the city, and aims to re-balance the territorial distribution of STR away from over-congested areas through a zoning system which bans new 
STR licenses in central areas, and allows a replacement, or modest growth, in other. The approval of the PEUAT, and the noticeable strengthening of enforcement measures that has accompanied it, were met with polarized reactions from the diverse actors involved in the debates on PM-STR, as discussed later. The regulation does not include 'home-sharing' in a strict sense (type (iii)). However, a new regulation was drafted by the Catalan government in 2016 to create a legal definition for home-sharing which, if eventually passed, will give city councils the discretion to create local regulations of this sub-type of STR through the existing licensing and land use planning system.

\section{Paris: the key role of local officials - housing versus tourism, city versus central state}

The case of Paris illustrates a different framing process - one heavily shaped by local officials and marked by tensions between policy sectors and scales of government. While PM-STR were initially seen as an economic opportunity to foster tourism attractiveness, the issue was reframed by the Deputy-Mayor for Housing as a problem that undermines the objectives of the housing policies implemented by the Socialist Party which has governed the city since 2001.

The category of short-term 'furnished tourist rentals' (type (i)) had been regulated in France since the 1960s in various legal texts (e.g. the Code of Tourism and Code of Urban Planning). In Paris, as renting out a property under that regime has been more profitable than renting out for a longer period, many property owners turned to that activity. The municipal government had been concerned about this for some time. To carry out this activity in large French cities, since 2005 a national law requires an official declaration of change of use from 'residential' to 'commercial', which is subject to authorization by the municipal government and to a 'compensation rule' (namely the compulsory provision of equivalent residential floorspace elsewhere in the city). These rules existed before the birth of platforms, but were not well publicised and hardly implemented. In 2011, two reports highlighted the adverse impacts caused by the rapid development of PM-STR (Gadeix, 2011; APUR, 2011) - illegalities, possible scams for tourists, nuisances for residents, and impacts on the housing market - and warned against Paris becoming a city for tourists rather than residents.

The city government consequently adopted a dual attitude. On the one hand, from 2013 onwards, the Housing Department - via the Office for Housing Protection - toughened controls on the 'change of use' and 'compensation' provisions and began to fine non-compliant landlords. On the other hand, the city government did not publicly put the issue on the political agenda until 2015, while platforms were increasing their offer in Paris at an exponential rate. The Department for Tourism and Economic Development saw this phenomenon as an opportunity to foster tourism attractiveness, while public opinion viewed it as a way for Paris residents to earn additional income - for type (ii) and (iii) - in one of the most expensive cities in the world. Unlike Barcelona, there have not been visible grassroots mobilizations in Paris against the impacts of tourism or gentrification. Criticisms against particular impacts of tourism came, rather, from upper middle-class associations in specific neighbourhoods (Gravari-Barbas and Jacquot, 2016). Since 2014, some of these associations have gradually embedded the issue of PM-STR into claims related to heritage conservation, quality of life, and local housing markets. The second wave of criticisms against PM-STR came 
from the hotel industry, which saw them as unfair competition and became more vocal at the same time as the mobilization of taxi drivers against Uber Pop in France in 2014 and 2015.

The year 2015 marked a turning point: PM-STRs emerged onto the local political agenda and were reframed as a housing issue by the municipal government after a conflict with the tourism department. As public debates around the negative effects of PM-STR were growing in other American and European cities, the Deputy-Mayor of Paris in charge of Cultural Affairs (Bruno Julliard, from the Socialist Party) invited the CEO of Airbnb, Brian Chesky, to the City Hall, to discuss the possibility of Airbnb collecting the city's tourist tax via its platform. However, the cordial tone of that meeting was brushed aside by the Deputy-Mayor for Housing (Ian Brossat, from the Communist Party) who reframed the issue of PM-STR as a housing problem. He pushed for a stronger display of municipal regulatory action, and shortly afterwards ordered a heavy control and enforcement action against illegal STR which received a lot of media coverage. Back then, the 'public problem' of PM-STR was not attributed to Airbnb or to tourists themselves, but to hosts who operate several properties, through a discursive cleavage between the "good" hosts (involved in home-sharing or the occasional renting of their primary residence, i.e. type (ii) and (iii)), and the "bad" ones driven by speculative goals (type (i)). Aligning with its middle class political clientele, the municipal government thus positioned itself against real estate speculation, but without condemning home-sharing as a practice. A new set of compromise rules were agreed upon, allowing individuals, after registration with the city administration, to rent their primary residence for up to 120 days per year without the need for a 'change of use' authorization needed for type (i). Short-term subletting by a tenant without authorization from the landlord, multi-listings, and PM-STR in social housing, are all prohibited. At the same time the door was left open to negotiate with Airbnb: in October 2016, the city government reached a tax collection agreement with the platform.

In parallel, the Paris government made repeated demands on the central government for a national regulation of platforms. Following a Parliamentary report arguing that the 'collaborative economy' was both an economic opportunity and a risk (Terrasse, 2016), the national "Law for a Digital Republic" was voted in October 2016. It allows cities over 200,000 inhabitants to require platforms to include a compulsory registration number in hosts' listings. However, the French Government - afraid of possible challenges in the European Court of Justice - did not sign the enforcement decree for some of the Law's provisions (particularly those asking platforms to share hosts' data with public authorities), following lobbying pressures from Airbnb and the European Holidays Home Association. A new national law on housing was voted in April 2018, which allows stronger sanctions against non-compliant platforms - but has not yet been validated by the government. At the national level, the overall framing of PM-STR, at the time of writing, was dominated by an economic rationale (influenced by the Ministry of Economy and by President Macron) rather than a housing protection rationale (upheld by the Ministry of Housing).

\section{Milan: the parallel mobilisation of 'sharing economy' advocates and the hotel industry}

Milan is a case where PM-STRs were first framed as an economic opportunity driven by the new 'sharing' economy, in the context of a political consensus around the desirable growth of the visitor economy. The regulatory initiatives by both the city and regional governments have 
been focused on economic development (in combination with social and redistributional objectives for the municipal government) and on the reduction of informality and tax evasion in relation to PM-STR, while national policy-making on the issue has been limited and exclusively tax-related.

In Milan, the first group to mobilise around PM-STR was a coalition of 'sharing economy' advocates set up in the run-up to the World Expo held in the city in 2015. In November 2013, during the first edition of the festival for the sharing economy "Sharitaly", 14 experts advocated the integration of the sharing economy into the upcoming mega-event, to transform Milan into a "Sharing City". These recognised experts belonged to well-established organisations in the city, including a major non-profit foundation, consultancy and university, and had strong individual ties with the city government. In their project (Sharexpo, 2014), six sectors (accommodation, mobility, working spaces, personal services and care, food, and culture) were taken as the starting points for the creation of a city-wide network of sharing services. Throughout 2014, this group, organised in the "Sharexpo" committee, played a key role in the emergence of the municipal "Milano Sharing City" policy, through public dissemination events and contacts with local policy-makers. The 'sharing economy' was therefore integrated into the agenda of the centre-left city government (in power since 2011 after 18 years of right-wing rule), around the goal of combining economic growth with social inclusion through new technologies (Gascó et al., 2016), public participation and service coproduction (Pais et al., forthcoming). The document "Milano Sharing City" was approved in December 2014 (Comune di Milano, 2014), spelling out a policy strategy for supporting new public and private sharing services and products in a more sustainable and inclusive economy (Mazzucotelli and Pais, 2017; Bernardi and Diamantini, 2016).

Three main characteristics of this municipal policy can be pointed out. First, it recalled the theorisations of the 'sharing economy' in its initial "golden age", defined as a new form of interpersonal exchanges that activate idle or underused resources and establish new social relations, forms of reciprocity and personal ties (Botsman and Rogers, 2011). Second, it had a cross-sectoral scope that cut through traditional policy fields: it was supported by three deputy-mayors - in charge of Employment and Economic Development, Mobility, and Commerce - who mobilized relevant actors (associations, profit and non-profit companies, etc.) to bring their activities and products into a coherent framework through network building. Third, in this context PM-STR were seen as only one of the various expressions of the 'sharing economy' (i.e. type (ii) and (iii)), and the platform Airbnb was considered as one of its operators. The company participated in the Milan Sharing City consultations and joined the municipally-labelled 'network of sharing economy operators' in 2015. A memorandum of understanding was signed between Airbnb and the municipality in November 2015, which included four types of actions: enhancement of the digital literacy of disadvantaged citizens; impact measurement from Airbnb; collaboration for increasing the accommodation offer during big events; and support for the implementation of the legal and tax rules defined by the recently approved Regional Law, expected to lead to the online collection of the tourist tax by the platform.

In parallel, a second and very different process of issue-framing and agenda-setting took place at the regional level, where PM-STR have been framed as a new, and largely informal, type of tourist accommodation. In 2015, the elaboration of a new regional law on tourism was 
triggered by the upcoming World Expo, with the aim of updating norms and stimulating tourism flows to the region. This opened a window of opportunity for the hotel industry to put the STR issue on the regional agenda, pushing for stricter legal norms and harder controls on STR. Their much-repeated slogan was "same market, same rules" (tax, quality, safety rules, etc.). They also criticised the term "sharing" for misrepresenting the full-time operation of many STR (type (i)) - to them, an irregular and unfair form of competition. In Milan, these economic actors are organised in well-established associations (Associazione Provinciale Albergatori Milano, Associazione Turismo e Ricettività and Assolombarda). Their actions targeted politicians and top civil servants (with whom they have well established ties), but also entailed active public campaigning through local media interventions, public conferences, reports, and the creation of an advocacy website, "HotelvsAirbnb".

The new regional law was approved in October 2015 by the ruling right-wing majority led by a Northern League governor, with no coordination with the city of Milan. As PM-STR did not fit any of the existing types of tourist accommodation, the law introduced a new category for PM-STR - the "Case e Appartamenti per Vacanza", subject to requirements similar to those applying to Bed\&Breakfast establishments, and applying to types (i), (ii) and (iii). The law was modified in January 2018 with the introduction of a compulsory identification number for landlords (starting from September 2018), a demand coming from the hotel industry. While these rules were criticised by both Airbnb and property-owners associations, the regional government defended the law not as an attempt to ban PM-STR, but to make this economic activity legal, measurable, taxable and safe, and to re-establish a fair competition with hotels. On the ground of this framing focused on legality and tourist tax collection, the municipal and regional governments have eventually started to cooperate since the end of 2016.

\section{The politicization of PM-STR, actors' mobilisation and the contested politics of regulation: a comparative analysis}

This section compares the results of the three case-studies first, to explain the different processes and factors that have led to different types of regulations; second, to analyse how the enacted regulations (their legitimacy, degree of stringency and instruments) have been the object of intense political mobilisation by different types of organised urban actors with clashing interests and narratives regarding the urban land use and the economic activity represented by PM-STR.

\section{Explaining the adoption of different regulations: actors, multi-level governance, instruments}

Three main factors emerge from the comparison to explain the variations in the regulations: the type of actors who politicized the issue in the first place, the distribution of competences between scales of government and the existing instruments available to the city administration. In Table 2 we show the types of actors centrally involved in the politicization and framing of PM-STR: in Barcelona, residents' associations and new grassroots movements against gentrification and touristification; in Paris, the hotel industry and the city government's housing officials - against officials from the tourism and economic development sectors; in Milan, 'sharing economy' advocates (at the local level) and the hotel industry (mostly at the regional level) in the context of an overall consensus favourable to tourism growth. 


\section{Table 2: Actors involved in the politicization and framing of PM-STR}

Importantly, the dominant actors active in framing the issue of PM-STR in each city (indicated with ++ in Table 2) have mobilized in an already institutionalized political space where policy makers have to deal with many problems. These actors therefore play a crucial role in coupling the framing of PM-STR with pre-existing issues that have been high on the broader political agenda - which are themselves the result of socio-political framing processes. In Barcelona, after May 2015 the governance of tourism and the 'right to housing' became central objectives of the new municipal government led by Barcelona en Comú, which sought to respond to grassroots' discontent about mass tourism and demarcate themselves from the previous centre-right government. By contrast, in Paris, mass tourism has not been politicized. The agenda-setting came from within the local government, with an unexpected alliance between local housing officials and the hotel industry who agreed on the need to regulate PM-STR with two different objectives (affordable housing protection vs preventing unfair competition). The city government also decided to regulate PM-STR because the central state did not: the local agenda must be understood through the lens of a historical conflict between the City of Paris and the French state. In Milan, the regional and municipal governments had pro-tourism agendas before the emergence of PM-STR. Regulatory initiatives were triggered by the World Expo 2015, to update norms in a light way to support tourism while addressing tax evasion and informality. At the municipal level, the PM-STR issue was anchored in a broader agenda for economic development and social inclusion through the promotion of the sharing economy'. At the time when regulations were passed, tourism flows were not considered significant enough to be an issue, and there was no problematization of a 'housing crisis' related to PM-STR in Milan.

As shown in Table 3, these framing processes have led to various modes of regulation with different levels of stringency. The framing and the policy sector in which the 'public problem' is located partly shape the way rules are enacted, but this is not the sole explanatory factor of variation. The latter also depends on the existing competences of the city government in relation to other tiers of government and the bargaining between them. In all three cases, it is either the regional government (Catalonia, Lombardy) or the national government (France) which has competence over the legal definition of tourism-related establishments, not the city governments. There may be tensions, or a lack of cooperation, between and within those different tiers vis-à-vis the need to regulate PM-STR. This may be due to ideological differences between the ruling parties at the regional and local level (with centre-right parties governing Lombardy and Catalonia and left-wing governments in Milan and Barcelona) and at the national and local level (in France). This may also be caused by tensions and unequal power relations between various sectorial administrations (e.g. the Ministry of Economy in France, which dominates the Ministry of Housing). One crucial element is whether regional or national legislation defines (different subtypes of) STR as an economic/commercial activity different from a residential use, thus potentially subject to an authorisation, registration or licensing system. If so, this gives scope for municipal governments to 'customise' the higher-tier rules and enact more stringent STR regulations using their competence over local land use planning to regulate changes of uses (Paris) or the granting of new licenses (Barcelona). 
Finally, the third factor shaping the adopted regulations are the existing policy instruments traditionally used in the sector(s) chosen to intervene (namely the 'compensation system' for 'change of use' in Paris; land use planning in Barcelona; the legal qualification of the types of tourist accommodation in Milan). These instruments are recycled, stretched or adapted to grasp different types of PM-STR. In Barcelona, the PEUAT was elaborated as a special planning document to avoid the lengthy process of modifying the General Metropolitan Plan, and some innovations in enforcement were devised (see Table 3). In Paris, existing instruments have been recycled with minor innovations, and given more visibility through a stricter enforcement of the long-existing national legislation on furnished tourist rentals. The Milan city government has, by contrast, developed a rather innovative, multi-sectorial 'sharing economy' policy agenda, but enacted only a light regulation of PM-STR (shaped by regional legislation).

Table 3: The regulation of PM-STR in Barcelona, Paris and Milan (as of June 2019)

After their adoption, the implementation of the new regulations - an aspect which cannot be developed in this paper - is highly challenging. As noted by other scholars, enforcing regulation is very difficult, as public authorities have limited capacity for the inspection of STR uses (Leshinsky and Schatz, 2018). The governments of the three cities have dedicated starkly different amounts of resources to that task (see Table 3). More crucially, city governments lack access to the data that would allow them to identify who exactly is offering a STR on a digital platform, in what capacity, at which precise location and for what amount of time, as most platforms have refused to communicate such personal data to public authorities (invoking European data protection legislation).

\section{The contentious politics of regulation and the reconfiguration of collective action: competing actors, interests and narratives}

In all three cities, the controversies around the adoption of PM-STR regulations have thus continued after their enactment. The mechanisms and legitimacy of the new regulations are at the core of intense debates: interest groups challenge the rules, seek to change them in directions that are favourable to their interests, or try to avoid compliance. Our empirical analysis identified six types of interest groups involved in the contentious politics of PM-STR regulations: the professional organisations representing the operators of legal, commercial STR; new associations of 'hosts' or of 'home-sharers'; the hotel industry; residents' associations; 'sharing economy advocates'; and corporate platforms. While some are old and well-established (such as hotel industry associations), others have emerged with the development of PM-STR and have become new and powerful urban actors (such as hosts' associations or platforms themselves). Interestingly, some unlikely discursive alliances have emerged between very different or traditionally opposed actors (e.g. hotel industry associations and grassroots movements), sometimes leading to actual collaboration for ad hoc actions. 
Figure 1 represents this contentious politics by summarizing the six types of actors, and the clashing 'rights' which they claim in their policy narratives for or against regulation. ${ }^{2}$ The horizontal axis represents the tension between those narratives emphasizing PM-STR as an economic activity (which should or should not be subject to licensing, fair competition or market access rules, taxation and other constraints), and those focusing on STR as a residential unit (which should or should not be regulated in relation to other land uses, with reference to 'public interest' considerations which may justify limiting private property rights). The vertical axis represents the tension between those narratives prioritizing the exchange value of PMSTR as a profit-making activity relying on a commodity to be exchanged according to supply and demand, and those defending the use value of residential units against their conversion into STR, or advocating the social and collective benefits of the practice of sharing one's home (as per the spirit of the early 'sharing economy' movement).

Figure 1. Competing actors around the regulation of PM-STR: clashing policy narratives and rights

The six types of actors and their claims are as follows:

1) The professional organisations representing the operators of legal, commercial STR or property managers (APARTUR in Barcelona, SPLM in Paris, Rescasa in Milan) tend to declare themselves favourable to some regulation and call for strong enforcement measures that protect them from the competition from their "illegal" STR-operating counterparts. At the same time, they firmly oppose any regulatory attempt to curb or slow the STR market and their entrepreneurial activities (such as the overall 'zero growth' in STR licences set by the Barcelona PEUAT).

2) New associations of hosts or of 'home-sharers' (ProLocaTur, Host Italiani, Home Sharing Club Milano, and then OspitaMi and Hospres in Milan, Plataforma Pro Viviendas Turísticas and Veïns i Amfitrions in Barcelona, Home Sharing Club Paris in Paris), while diverse in their composition (some representing 'home-sharers' in the strict sense, i.e. type (ii) and (iii), some representing individual operators of full STR units, i.e. type (i)), have been very vocal against new (or prospective) regulations, which they describe as limiting their individual right to rent/share in a context of austerity and/or to freely use their property. This type includes the so-called "Home sharing clubs" whose creation was encouraged by Airbnb.

3) By contrast, the hotel industry systematically supports a tougher approach to PM-STR in the three cities, seeing PM-STR as 'unfair competition' and demanding that they be subject to the same set of rules that apply to hotels, to uphold the principles of a 'levelplaying field'. In the three cities they draw material, financial and legitimacy resources from being part of larger national business- and hotel federations.

4) Many residents' associations (in Paris, mostly middle-class, quality-of-life focused; in Barcelona, more heterogeneous and in cooperation with other grassroots movements such as the ABTS and housing activists) support the new regulatory measures, in the

\footnotetext{
2 The word 'right' has been explicitly used by some actors in policy documents or interviews (e.g. the city administration in Barcelona; or Airbnb and home-sharing associations). Other actors referred to broader principles like 'free enterprise' or 'fair competition' in their legitimizing narratives.
} 
name of the individual right to 'peace' and 'privacy' and/or of the collective 'right to housing' and to 'stay put'. But often they deem the new rules too mild or lacking 'teeth' because of poor enforcement resources or not enough pressures put on platforms.

5) 'Sharing economy' intellectual advocates inspired by the initial theorisations of this movement seek to harness the technological innovation provided by platforms to encourage the activation of underused urban resources and simultaneously support objectives of economic growth, social cohesion, public participation and service coproduction (they were mostly present in the Milan case).

6) Finally, corporate platforms, especially Airbnb, have played a dominant role in the local, regional or national politics of PM-STR regulation in the three cities, publicly invoking the 'right to share' (sometimes supported, at least initially, by pro-sharing economy intellectual advocates as in Milan), and the 'right to travel' (or mobility) (illustrated by Airbnb's slogans "belong anywhere" and "live like a local").

With regard to corporate platforms, in our three cases they have developed intense political actions at various levels of government, confirming other studies such as McNeill, 2016. Relations between platforms and local governments have oscillated between "political exchange" (Pizzorno, 1978) and "policy conflict" (Dobbin, 2004). On the one hand, platforms have sought political recognition to reduce the regulatory risk inherent to the legal grey area in which their business operates, thus offering some degree of collaboration on particular aspects of policy implementation. This was the case with Airbnb in Milan and Paris in 2015 and 2016. On the other hand, strong conflicts between platforms and public authorities also occurred. In July 2014 the Barcelona government fined Airbnb and seven other platforms $€ 30,000$ each, and in November 2016 Airbnb and Homeaway $€ 600,000$ each, for repeatedly advertising illegal listings despite warnings. Airbnb then expressed virulent critiques against the restrictive nature of the PEUAT in Barcelona, or the introduction of minimum regulatory requirements in Lombardy and the registration number in Paris. Moreover, Airbnb has developed new strategies of political influence based on the mobilisation of the platform's individual users, who are encouraged to mobilise against attempts to regulate the sector collectively via the above-mentioned "Home sharing clubs" and the platform's dedicated policy website (airbnbcitizen.com), and individually via "protest" e-mails pre-drafted by Airbnb. Such practices are not unique to Airbnb, but common to several corporate actors in the platform economy (see Thelen, 2018, on Uber). Airbnb and other major platforms thus act as 'regulatory entrepreneurs' (Pollman and Barry, 2017), and, we argue, have become a new significant urban governance actor. Beyond the intense political actions of the platform at the local level, further analysis of this new 'regulatory entrepreneurship' is necessary at upper levels of government - in particular at the EU level, which is becoming an increasingly important battleground for regulation as platforms turn to the European E-Commerce Directive and Services Directive to contest new regulations (Corporate Europe Observatory, 2018).

\section{Conclusion}

The development of digital platforms has greatly facilitated the proliferation of short-term rentals, a type of economic activity and urban land use which previously existed in limited 
forms. This has contributed to change global mobility patterns, opened new markets for real estate investment and rent extraction, and challenged traditional modes of regulation, forcing public institutions to deal with informal, hard-to-measure practices and new transnational companies. PM-STR thus reveal a new facet of the influence of corporate capitalism over cities. Comparative work on these issues is crucial to understand how different countries and cities are 'confronting the challenges posed by the advent of digital capitalism' in very different ways (Thelen, 2018: 939). The paper analysed how and why the city governments of Barcelona, Paris and Milan developed different regulatory responses to this transnational phenomenon. The comparison allowed us to identify three factors that contribute to explain different regulatory responses: the type of actors who mobilised in the first place, multi-level government arrangements and pre-existing policy instruments. Furthermore, we identified the main actors involved, and the different types of interests and rights which are counterposed, in the contentious politics of PM-STR regulation. Conflicts emerge in all cities around who has a 'right' to live in/enjoy the city and to get a share of the benefits of 'platform capitalism', and around the rationale and conditions under which the right to use one's property or to freely carry out an economic activity can be curtailed or regulated.

Our comparative analysis of the development of responses by different actors adds richness to the scholarship on 'platform economies' and urban change by providing a grounded understanding of the emergence and consolidation of place-specific discursive framings and policy responses to the issue of PM-STR. It shows that new forms of corporate 'digital capitalism' do not land homogeneously upon cities, and calls for further comparative analyses of local processes of actors' mobilization, collective action, and modes of regulation of digital platforms. City (and other tiers of) governments may not be completely powerless in the face of new transnational digital corporations, although they are struggling to deal and negotiate with them. The future effectiveness of regulations depends on the success of the pressures put by public actors - at multiple tiers of government, including the EU - on platforms for access to data and regulatory compliance. While there was no scope here to elaborate on this crucial question, the challenges of 'governing without data' - or with imperfect data - in the age of global digital capitalism and privately-produced big data (Courmont \& Le Galès, 2019) should be a central focus of contemporary urban studies scholarship.

\section{Acknowledgements}

The authors would like to thank Tatiana Moreira de Souza for her crucial help with the broader comparative project of which this paper is a part, as well as all the interviewed actors in the three cities who shared their insights with us. We also thank the editors of the special issue, Agustin Cocola-Gant, Angela Hof, Christian Smigiel and Ismael Yrigoy for their invitation to contribute, and the anonymous reviewers for their constructive comments. Finally, the collaboration between the authors was born as part of the "What is (not) Governed in the Large Metropolis" intellectual project, led by Patrick Le Galès at Sciences Po Paris: thanks to the WHIG network of colleagues for their support and feedback at various stages of this comparative project. 


\section{References}

(All URL last accessed 9 June 2019)

Airbnb (2018) The economic impacts of home sharing in cities around the world. Available at: https://www.airbnb.co.uk/economic-impact.

Ajuntament de Barcelona (2017) About the PEUAT (Special Tourist Accommodation Plan). Available at: http://ajuntament.barcelona.cat/pla-allotjaments-turistics/en.

Aalbers M (2016) The Financialization of Housing. A Political Economy Approach. London: Routledge.

APUR Atelier Parisien d'Urbanisme (2011) Les locations meublées de courte durée à Paris. Etat des lieux et propositions. Paris: APUR.

APUR (2018) Short-term rentals: an analysis of metropolitan public responses. Note no. 128. Paris: APUR.

Artioli F (2018) Digital platforms and cities: a literature review for urban research. Cities are back in Town Working Papers, No. 01/2018. Paris: Sciences-Po Urban School.

Barron K, Kung E and Proserpio D (2017) The Sharing Economy and Housing Affordability: Evidence from Airbnb. SSRN Scholarly Paper ID 3006832. Rochester, NY: Social Science Research Network.

Becker H (1963) Outsiders: Studies in the Sociology of Deviance. New York: Free Press.

Bernardi M and Diamantini D (2016) I modelli di governance della sharing economy. Due casi a confronto: Milano Sharing City e Sharing City Seoul. In: Bassoli M and Polizzi E (eds) Le politiche della condivisione. La sharing economy incontra il pubblico. Milano: Giuffrè, pp. 107 - 138.

Botsman R and Rogers R (2011) What's Mine Is Yours: The Rise of Collaborative Consumption. London: HarperCollins Business.

Cobb R and Ross M (1997) Cultural Strategies of Agenda Denial: Avoidance, Attack, and Redefinition. Lawrence: University Press of Kansas.

Cócola Gant A (2016a) Holiday rentals: The new gentrification battlefront. Sociological Research Online 21(3). Available at: http://www.socresonline.org.uk/21/3/10.html.

Cócola Gant A (2016b) Apartamentos turísticos, hoteles y desplazamiento de población. Available at: www.agustincocolagant.net.

Cócola Gant A (2018) Tourism gentrification. In: Lees L and Phillips M (eds) Handbook of Gentrification Studies. Cheltenham: Edward Elgar, pp. 281-293. 
Colau A (2015) Mass tourism can kill a city - just ask Barcelona's residents. The Guardian, 2 September.

CEO Corporate Europe Observatory (2018) UnFairbnb. Brussels: CEO.

Comune di Milano (2014) Milano Sharing City. Available at: http://www.milanosmartcity.org/joomla/sharing-economy/milanosharingcity.

Courmont A (2018) Plateforme, big data et recomposition du gouvernement urbain. Les effets de Waze sur les politiques de régulation du trafic. Revue Française de Sociologie 59(3): 423449.

Courmont A and Le Galès P (eds) Gouverner la Ville Numérique. Paris: PUF, La Vie des Idées.

Cress D and Snow D (2000) The outcomes of homeless mobilization: the influence of organization, disruption, political mediation and framing. American Journal of Sociology 105(4): 1063-1104.

Crommelin L, Troy L, Martin C and Pettit C (2018) Is Airbnb a sharing economy superstar? Evidence from five global cities. Urban Policy and Research. Epub ahead of print 28 May. DOI: $10.1080 / 08111146.2018 .1460722$.

Deverteuil G and Manley D (2017) Overseas investment into London: imprint, impact and pied-a-terre urbanism. Environment and Planning A 49(6): 1308-1323.

Dobbin F (eds) (2004) The New Economic Sociology. A Reader. Princeton University Press.

Dredge D, Gyimóthy S, Birkbak A, Jensen TE and Madsen AK (2016) The impact of regulatory approaches targeting collaborative economy in the tourism accommodation sector: Barcelona, Berlin, Amsterdam and Paris. Impulse Paper No 9 prepared for the European Commission DG GROWTH. Copenhagen: Aalborg University.

Dredge D and Gyimóthy S (2017) Tourism and Collaborative Economy. Cham: Springer.

Eizaguirre S, Pradel-Miquel M and García M (2017) Citizenship practices and democratic governance: 'Barcelona en Comú' as an urban citizenship confluence promoting a new policy agenda. Citizenship Studies 21(4): 425-439.

Ferreri M and Sanyal R (2018) Platform economies and urban planning: Airbnb and regulated deregulation in London. Urban Studies. Epub ahead of print 28 February. DOI: 10.1177/0042098017751982.

Fischer F (2003) Reframing Public Policy. Oxford: Oxford University Press.

Gadeix D (2011) Locations meublées de courte durée. Point sur la pratique. Paris: ANIL. 
Gascó M, Trivellato B and Cavenago D (2016) How Do Southern European cities foster innovation? Lessons from the experience of the smart city approaches of Barcelona and Milan. In: Gil-Garcia JR, Pardo TA and Nam T (eds) Smarter as the New Urban Agenda. Cham: Springer, pp. 191-206.

Gottlieb C (2013) Residential short-term rentals: Should local governments regulate the 'industry'? Planning and Environmental Law 65(2): 4-9.

Gravari-Barbas M and Guinand S (eds) (2017) Tourism and Gentrification in Contemporary Metropolises. International Perspectives. London: Routledge.

Gravari-Barbas M and Jacquot S (2016) No conflict? Discourses and management of tourismrelated tensions in Paris. In: Colomb C and Novy J (eds) Protest and Resistance in the Tourist City. London: Routledge, pp. 31-51.

Gurran N (2018) Global home-sharing, local communities and the Airbnb debate: a planning research agenda. Planning Theory and Practice 19(2): 298-304.

Gurran N and Phibbs P (2017) When tourists move in: how should urban planners respond to Airbnb? Journal of the American Planning Association 83(1): 80-92.

Guttentag D (2015) Airbnb: disruptive innovation and the rise of an informal tourism accommodation sector. Current issues in Tourism 18(12): 1192-1217.

Hall P (1986) Governing the Economy: The Politics of State Intervention in Britain and France. Oxford: Oxford University Press.

Holman N, Mossa A and Pani E (2018) Planning, value(s) and the market: An analytic for "what comes next?" Environment and Planning A 50(3): 608-626.

Hood C (1983) The Tools of Government. London: Macmillan.

Lees L, Shin H and Lopez-Morales E (eds) (2015) Global Gentrifications: Uneven Development and Displacement. Bristol: Policy Press.

Leshinsky R and Schatz L (2018) "I don't think my landlord will find out:" Airbnb and the challenges of enforcement. Urban Policy and Research, 36(4): 417-428.

Locke R and Thelen K (1995) Apples and oranges revisited: contextualized comparisons and the study of comparative labor politics. Politics \& Society 23(3): 337-67.

Mazzucotelli Salice S and Pais I (2017) Sharing economy as an urban phenomenon: examining policies for sharing cities. In: Meil P and Kirov V (eds) Policy Implications of Virtual Work. London: Palgrave, pp. 199-228.

McNeill D (2016) Governing a city of unicorns: technology capital and the urban politics of San Francisco. Urban Geography 37(4): 494-513. 
Mendes L (2018) Tourism gentrification in Lisbon: The panacea of touristification as a scenario of a post-capitalist crisis. In: David I (ed.) Crisis, Austerity and Transformation: How Disciplinary Neoliberalism is Changing Portugal. London: Lexington, pp. 25-46.

Milano C (2017) Overtourism and Tourismphobia: Global trends and local contexts. Barcelona: Ostelea School of Tourism and Hospitality.

Muller P (1985) Un schéma d'analyse des politiques sectorielles. Revue Française de Science Politique 35(2): 165-189.

Nieuwland S and van Melik R (2018) Regulating Airbnb: how cities deal with perceived negative externalities of short-term rentals. Current Issues in Tourism. Epub ahead of print 3 August. DOI: 10.1080/13683500.2018.1504899

Novy J and Colomb C (2016) Urban tourism and its discontents: an introduction. In: Colomb C and Novy J (eds) Protest and Resistance in the Tourist City. London: Routledge, pp. 1-30.

Novy J and Colomb C (2019) Urban tourism as a source of contention and social mobilisations: A critical review. Tourism Planning \& Development 16(4): 358-375.

Pais I, Polizzi E and Vitale T (forthcoming) Governare l'economia collaborativa per produrre inclusione: Attori, strumenti, stili di relazione e problemi di implementazione. In: Andreotti A (ed) Milano Città Plurale: Attori Pubblici e Privati in Movimento. Bologna: II Mulino.

Palombo D (2015) A tale of two cities: the regulatory battle to incorporate short-term residential rentals into modern law. American Business Law Review 4(2): 287-320.

Paris C (2009) Re-positioning second homes within housing studies: household investment, gentrification, multiple residence, mobility and hyper-consumption. Housing, Theory and Society 26(4): 292-310.

Pickvance C (2001) Four varieties of comparative analysis. Journal of Housing and the Built Environment 16: 7-28.

Pizzorno A (1978) Political exchange and collective identity in industrial conflict. In C Crouch and Pizzorno A (eds) The Resurgence of Class Conflict in Western Europe since 1968. London: Palgrave, pp. 277-298.

Pollman E and Barry JM (2017) Regulatory entrepreneurship. Southern California Law Review 90(3): 383-448.

Prayag G and Ozanne LK (2018) A systematic review of peertopeer (P2P) accommodation sharing research from 2010 to 2016: progress and prospects from the multi-level perspective. Journal of Hospitality Marketing and Management. Epub ahead of print 13 February. DOI: 10.1080/19368623.2018.1429977. 
Radaelli C (1999) Harmful Tax Competition in the EU: Policy Narratives and Advocacy Coalitions. Journal of Common Market Studies 37(4): 661-682.

Robinson J (2011) Cities in a World of Cities: The comparative gesture. International Journal of Urban and Regional Research 35(1): 1-23.

Rose R and Davies P (1994) Inheritance in Public Policy. Change without Choice in Britain. New Heaven: Yale University Press.

Russo AP and Scarnato S (2018) "Barcelona in common": A new urban regime for the $21^{\text {st }}$ century tourist city? Journal of Urban Affairs 40(4): 455-474.

Schäfer P and Hirsch J (2017) Do urban tourism hotspots affect Berlin housing rents? International Journal of Housing Markets and Analysis 10(2): 231-255.

Schor JB and Attwood C (2017) The "sharing" economy: labor, inequality, and social connection on for-profit platforms. Sociology Compass 11(8) online. Available at: https://doi.org/10.1111/soc4.12493.

Srnicek N (2017) Platform Capitalism. Cambridge: Polity.

Sharexpo (2014) Documento d'Indirizzo Sharexpo: Milano città condivisa per Expo 2015. Available at: https://issuu.com/sharexpo/docs/documento d indirizzo sharexpo/7.

Sharp D (2018) Sharing cities for urban transformation: narrative, policy and practice. Urban Policy and Research. Epub ahead of print 24 January. DOI: 10.1080/08111146.2017.1421533.

Slee T (2016) What's Yours is Mine: Against the Sharing Economy. New York: Or Books.

Smorto G (2016) Impulse Paper on the Business Authorisation/Licensing Requirements Imposed on Peer-Providers and Platforms in the Accommodation/Tourism Sector in Paris, Rome, Milan and London. Impulse Paper No. 2 prepared for the European Commission DG GROWTH. Palermo: University of Palermo.

Stabrowski F (2017) 'People as businesses': Airbnb and urban micro-entrepreneurialism in New York City. Cambridge Journal of Regions, Economy and Society 10(2): 327-347.

Terrasse P (2016) Rapport au Premier Ministre sur l'économie collaborative. Paris: Hôtel de Matignon.

Thelen K (2018) Regulating Uber: the politics of the platform economy in Europe and the United States. Perspectives on Politics 16(4): 938-953.

Tilly C (1984) Big Structures, Large Processes, Huge Comparisons. New York: Russell Sage Foundation. 
Tussyadiah IP and Pesonen J (2018) Drivers and barriers of peer-to-peer accommodation stay - an exploratory study with American and Finnish travelers. Current Issues in Tourism 21(6): 703-720.

Wachsmuth D (2017) How do we measure Airbnb's impact on housing and gentrification? Available at: https://davidwachsmuth.com/2017/03/17/how-do-we-measure-airbnbsimpact-on-housing-and-gentrification/

Wachsmuth D, Kerrigan D, Chaney D and Shillolo A (2017) Short-term cities: Airbnb's impact on Canadian housing markets. McGill University: School of Urban Planning.

Wegmann J and Jiao J (2017) Taming Airbnb: Toward guiding principles for local regulation of urban vacation rentals based on empirical results from five US cities. Land Use Policy 69 (December): 494-501.

Widener, M N 2015. Shared Spatial Regulating in Sharing-Economy Districts. SSRN Scholarly Paper ID 2563795. Rochester, NY: Social Science Research Network.

Zervas G, Prosperio D and Byers J (2017) The rise of the sharing economy: estimating the impacts of Airbnb on the hotel industry. Journal of Marketing Research 54(5): 687-705. 
Table 1

\begin{tabular}{|c|c|c|c|}
\hline & Barcelona & Paris & Milan \\
\hline Population $^{1}$ & $\begin{array}{l}\text { 1,620,809 (2017) } \\
\text { (Greater City 3,648,483) }\end{array}$ & $\begin{array}{l}\text { 2,220,445 (2014) } \\
\text { (Greater City 6,754,282) }\end{array}$ & $\begin{array}{l}\text { 1,351,562 (2017) } \\
\text { (Greater City 4,087,060) }\end{array}$ \\
\hline Area (surface) & $101.9 \mathrm{~km}^{2}$ & $105.4 \mathrm{~km}^{2}$ & $181.8 \mathrm{~km}^{2}$ \\
\hline Total number of housing units ${ }^{2}$ & $811,106(2011)$ & $1,300,000(2016)$ & $643,053(2011)$ \\
\hline \multicolumn{4}{|l|}{ Structure of housing stock ${ }^{3}$} \\
\hline$\%$ of social/affordable housing & $5.9 \%(2011)$ & $19,9 \%(2016)$ & $5.5 \%(2016)$ \\
\hline$\%$ of home ownership & $64 \%(2011)$ & $33,2 \%(2015)$ & $59,6 \%(2001)$ \\
\hline$\%$ of privately rented housing & $30,1 \%(2011)$ & $44 \%(2014)$ & $34,9 \%(2001)$ \\
\hline$\%$ of vacant housing units ${ }^{4}$ & $10.9 \%(2011)$ & $7.3 \%(2011)$ & $6 \%(2011)$ \\
\hline Average rent in private sector ${ }^{5}$ & $10.3 € / \mathrm{m}^{2} /$ month $(2015, \mathrm{Q} 1)$ & $22.9 € / \mathrm{m}^{2} /$ month $(2018)$ & $24,8 € / \mathrm{m}^{2} /$ month $(2018)$ \\
\hline Gross available average income / capita ${ }^{6}$ & $20,600 €$ /inhab. (2015) & $26,431 € /$ household (2016) & $20,968 €$ /inhab. (2013) \\
\hline Rate of unemployment ${ }^{7}$ & $17.82 \%(2011)$ & $12.82 \%(2012)$ & $6.97 \%(2011)$ \\
\hline Number of tourists (number of bednights) ${ }^{8}$ & 19.16 million (2016) & 44.02 million (2016) & 11.26 million (2016) \\
\hline Number of hotels & 653 & 1,573 & 467 \\
\hline Number of hotel rooms ${ }^{9}$ & $76,972(2017)$ & $80,617(2017)$ & $27,519(2017)$ \\
\hline \multirow[t]{3}{*}{ Number of Airbnb listings ${ }^{10}$} & 12,000 (April 2015) & $25,000(2015)$ & $6,403(2014)$ \\
\hline & 18,346 (Nov. 2018) of which & 59,881 (Dec. 2018) of which & 17,659 (Nov. 2018) of which \\
\hline & $46.1 \%$ entire flats $\& 62.4 \%$ multi-listings & $86.8 \%$ entire flats $\& 19.9 \%$ multi-listings & $72,5 \%$ entire flats $\& 39.7 \%$ multi-listings \\
\hline Other estimates of STR numbers ${ }^{11}$ & $\begin{array}{l}\text { - Licensed STR: from } 824 \text { in } 2011 \text { to 9,606 in } \\
2015 \text { + unlicensed STR estimated at 6,275 in } \\
2015 \text { = total 15,881 (July 2015) } \\
\text { - January 2016: 78\% of 14,699 Airbnb listings } \\
\text { had no license number displayed }\end{array}$ & $\begin{array}{l}\text { Total PM-STR estimate (2018): } 100,000 \\
\text { (60,000 Airbnb + 40,000 other platforms) } \\
\text { - of which licensed STR (with registration } \\
\text { number): } 24,216 \text { apartments (2018) }\end{array}$ & $\begin{array}{l}\text { 2018: registered apartments (CAV) represent } \\
\text { no more than } 10 \% \text { of total Airbnb listings } \\
\text { (1,841 CAV out of } 17,657 \text { listings) }\end{array}$ \\
\hline
\end{tabular}

\footnotetext{
${ }^{1}$ Eurostat, Urban Audit

2 Idescat; INSEE; ISTAT

${ }^{3}$ Idescat; INSEE; ALER, ISTAT

${ }^{4}$ Idescat; INSEE; ISTAT

${ }^{5}$ Ajuntament de Barcelona, Estadística; Agence départementale d'information sur le logement (ADIL), Observatoire des loyers de l'agglomération parisienne (OLAP); Osservatorio Mercato

Immobiliare (OMI), Agenzia delle Entrate

${ }^{6}$ Ajuntament de Barcelona, Estadística; INSEE; Ambrosetti, ANCl, Intesa San Paolo (2016) Start City. Il rilancio parte da qui. Fascicolo 7, p. 13.

${ }^{7}$ Centre for Cities Data Tool based on Eurostat Labour market statistics.

${ }^{8}$ European Cities Marketing Benchmarking Report 2017

${ }^{9}$ Ajuntament de Barcelona, Estadística; INSEE; Comune di Milano Open Data

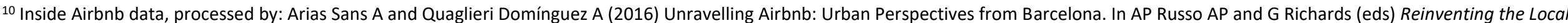

in Tourism. Bristol: Channel View, pp. 209-228; http://www.simonblum.me/post/hacks/airbnb-paris; http://tomslee.net/category/airbnb-data

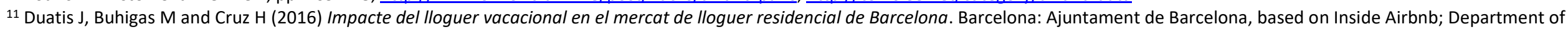
Housing, City of Paris; Regione Lombardia Open Data
} 
Table 2

\begin{tabular}{|c|c|c|c|c|c|c|c|c|}
\hline \multirow[t]{2}{*}{ Cases } & \multicolumn{5}{|c|}{ Actors involved in the framing } & \multicolumn{3}{|c|}{ Policy framing } \\
\hline & $\begin{array}{l}\text { Sectorial } \\
\text { and } \\
\text { business } \\
\text { federation } \\
s\end{array}$ & $\begin{array}{l}\text { Residents' } \\
\text { associatio } \\
\text { ns or } \\
\text { grassroots } \\
\text { movement } \\
s\end{array}$ & $\begin{array}{l}\text { 'Sharing } \\
\text { economy' } \\
\text { advocates }\end{array}$ & $\begin{array}{l}\text { P2P } \\
\text { Platforms }\end{array}$ & $\begin{array}{l}\text { Governme } \\
\text { nt }\end{array}$ & $\begin{array}{l}\text { Main claims } \\
\text { about STR } \\
\text { (diagnostic) }\end{array}$ & Main sector & $\begin{array}{l}\text { Policy } \\
\text { demands } \\
\text { (prognostic) }\end{array}$ \\
\hline $\begin{array}{l}\text { Barcelon } \\
\text { a }\end{array}$ & + & $\begin{array}{l}++ \\
\text { Residents' } \\
\text { association } \\
\text {, new } \\
\text { grassroots } \\
\text { movement } \\
\text { s }\end{array}$ & 0 & $\begin{array}{l}+ \\
\text { Mainly } \\
\text { Airbnb }\end{array}$ & $\begin{array}{l}++ \\
\text { Municipal } \\
+ \\
\text { Regional }\end{array}$ & $\begin{array}{l}\text { PM-STR are } \\
\text { part of } \\
\text { excessive } \\
\text { tourism } \\
\text { flows, disturb } \\
\text { daily life and } \\
\text { the housing } \\
\text { market }\end{array}$ & $\begin{array}{l}\text { Tourism + } \\
\text { Housing }\end{array}$ & $\begin{array}{l}\text { Almost } \\
\text { prohibition } \\
\text { and territorial } \\
\text { redistribution }\end{array}$ \\
\hline Paris & $\begin{array}{l}++ \\
\text { Hotel } \\
\text { industry }\end{array}$ & $\begin{array}{l}+ \\
\text { Conservati } \\
\text { onist } \\
\text { residents } \\
\text { association }\end{array}$ & 0 & $\begin{array}{l}+ \\
\text { Mainly } \\
\text { Airbnb }\end{array}$ & $\begin{array}{l}++ \\
\text { Municipal }\end{array}$ & $\begin{array}{l}\text { PM-STR } \\
\text { disturb the } \\
\text { housing } \\
\text { market }\end{array}$ & Housing & $\begin{array}{l}\text { Agreement } \\
\text { and } \\
\text { regulation to } \\
\text { control 'bad' } \\
\text { STR }\end{array}$ \\
\hline Milan & $\begin{array}{l}++ \\
\text { Hotel } \\
\text { industry }\end{array}$ & 0 & $\begin{array}{l}++ \\
\text { Academics, } \\
\text { think tanks } \\
\text { advising } \\
\text { city } \\
\text { governme } \\
\text { nt }\end{array}$ & $\begin{array}{l}++ \\
\text { Mainly } \\
\text { Airbnb }\end{array}$ & $\begin{array}{l}++ \\
\text { Municipal } \\
++ \\
\text { Regional }\end{array}$ & $\begin{array}{l}\text { PM-STR are } \\
\text { an economic } \\
\text { opportunity/ } \\
\text { a threat to be } \\
\text { managed, } \\
\text { regulated and } \\
\text { taxed }\end{array}$ & $\begin{array}{l}\text { Sharing } \\
\text { Economy, } \\
\text { economic \& } \\
\text { social } \\
\text { development } \\
\text { (municipal } \\
\text { level) } \\
\text { Tourism } \\
\text { (municipal \& } \\
\text { regional } \\
\text { level) }\end{array}$ & $\begin{array}{l}\text { Registration } \\
\text { and taxation }\end{array}$ \\
\hline
\end{tabular}


Table 3

Barcelona

Tier(s) of government \& Regional: tourism legislation (definition of

policy sector

'accommodation for touristic use')
Municipal: urban planning: special land use / zoning plan (PEUAT) which limits licences for new STR in the city

\section{Stringency / restrictive nature High}

(i) Commercial STR of full Allowed with a license. But de facto ban on new

property not used as a

residence

licenses in central areas of Barcelona since entry into

force of PEUAT on 6 March 2017 (and very limited

growth in other areas)

(ii) Temporary rental of primary residence (in full)

Allowed with a license. But de facto ban on new

licenses in central areas of Barcelona since entry into force of PEUAT on 6 March 2017 (and very limited

growth in other areas)

(iii) Home-sharing Currently "a-legal”. New regional legislation under discussion, not approved yet: would create a legal definition for STR of rooms in a primary residence and give scope for municipalities to regulate

\section{Mandatory registration of Registration on Tourism Register of Catalonia}

activity/unit (with light

conditions)

+ Communication of activity to Municipality

Other restrictions/obligations - Owners' association can decide blanket ban on use of flats as housing for touristic uses in a residential building through change in bylaws

Agreements with platforms

- Platforms obliged to inform hosts of local rules - Platforms obliged to inform hosts of local rules and
- June 2018: agreement with Airbnb to require newly-require them to include license number in ad

signed hosts to include licence number and accept-October 2015: Agreement with Airbnb for tourist tax sharing of personal data with city and regional collection via platform

National: various pieces of legislation on tourism and Regional: tourism legislation (definition of 'holiday

housing (definition and conditions for commercial

'furnished tourist rentals') and on the digital economy

Municipal: housing regulations (change of use from

residential to commercial) accommodation')

\section{Medium}

Subject to municipal authorization for change of use

(from residential to commercial) + compulsory

Municipal: economic development ('sharing city' strategy) compensation condition: acquire a commercial property elsewhere in city and convert it to resident

\section{Light}

Allowed up to 120 days per year subject to registration Allowed, subject to communication to Municipality.

Allowed, subject to communication to Municipality.

STR considered as commercial if more than 3 units rented or full-year rental. Tax regime of commercial activities

authorities

- April 2016: Airbnb sends out communications to hosts

likely to be renting primary residence for more than 120 days with Municipality

Type (i): Declaration of furnished tourist rental

and (iii): since 2016, registration with Municipality

For tenants: STR needs authorization from landlord STR considered as non-commercial if up to 3 units rented or if the rental is up to 275 days a year. Tax regime of non-commercial activities

Allowed up to 120 days per year subject to registration Allowed, subject to communication to Municipality. STR considered as non-commercial if up to 3 units rented or the rental is up to 275 days a year. Tax regime of non-commercial activities

Communication of start/end of activity to Municipality. The delivered Identification Code (CIR) must appear on listings and advertising (starting from Sept. 2018) - Obligation for hosts to communicate guests ID to the - For landlords: authorization needed from owners' association:

政 - Apartment and furniture standards for STR defined by law

Platforms obliged to inform hosts of local rules and require them to include the Identification Code

March 2018: Agreement with Airbnb for tourist tax collection via platform
Digital scraping, inspections
Inspections

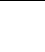

tong




\begin{tabular}{|c|c|c|c|}
\hline & $\begin{array}{l}\text { Staff: } 40 \text { 'visualisers' tracing online illegalities }+36 \\
\text { inspectors from municipal Dep. of Urban Planning } \\
\text { 2017: 4,963 proceedings against illegal STR }\end{array}$ & $\begin{array}{l}\text { Staff: } 29 \text { inspectors from municipal Office of Housing } \\
\text { Protection } \\
\text { 2017: } 212 \text { proceedings against illegal STR }\end{array}$ & $\begin{array}{l}\text { Staff: 10 inspectors from the Budget and Revenues } \\
\text { Dep. }\end{array}$ \\
\hline $\begin{array}{l}\text { Channels for reporting } \\
\text { illegalities }\end{array}$ & Yes (online + phone) & Yes (online) & Not specific to STR \\
\hline Fines & $\begin{array}{l}€ 3,000-€ 30,000 \text { (for illegal STR operators) } \\
€ 30,000-€ 600,000 \text { (for platforms not complying) }\end{array}$ & $€ 50,000$ (for illegal STR operators) & $\begin{array}{l}€ 2,000-€ 20,000 \text { for illegal STR operators; } € 2,000- \\
€ 10,000 \text { for unfulfilled STR requirements; } € 500-€ 2,500 \\
\text { for non-visible or fake code }\end{array}$ \\
\hline Other measures & $\begin{array}{l}\text { Online searchable register of licensed commercial STR } \\
\text { Communication campaign on posters for tourists }\end{array}$ & Public register of authorized commercial STR & Online searchable register of licensed commercial STR \\
\hline
\end{tabular}


Figure 1

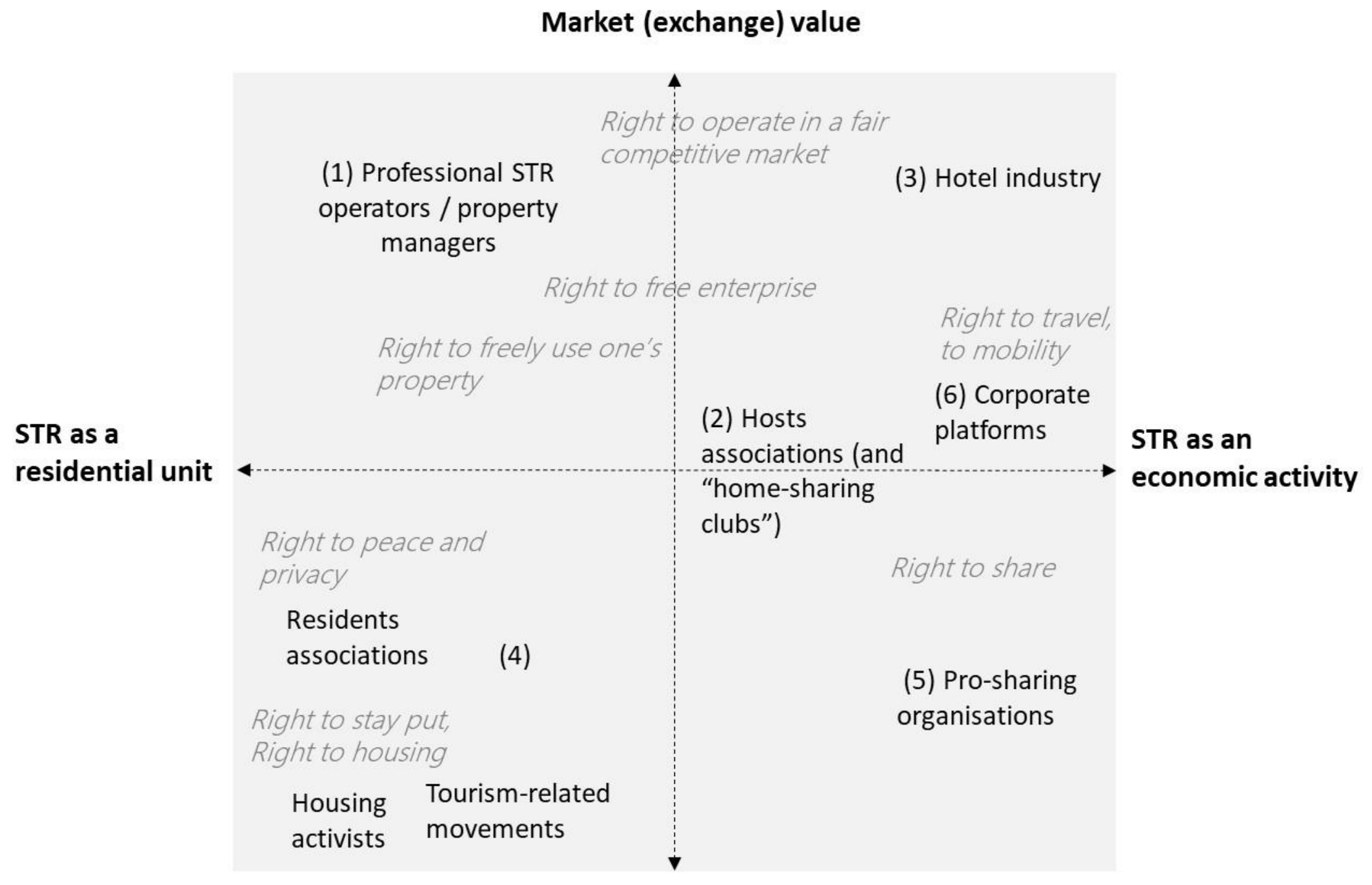

Use value 